\title{
FROM KADI TO NADA: JUDICIAL TECHNIQUES FAVORING HUMAN RIGHTS OVER UNITED NATIONS SECURITY COUNCIL SANCTIONS
}

\author{
Erika de Wet*
}

\begin{abstract}
The contribution analyzes the implications of the Kadi decision of the European Court of Justice of 18 July 2013, as well as that of the Nada decision of the European Court of Human Rights of September 2013. Both decisions have given preference to human rights standards over United Nations Security Council sanctions stemming from the Resolution 1267 (1999) sanctions regime. However, they used very different techniques in coming to similar results, with implications for the effective enforcement of UNSC binding decisions and the unity of international law.
\end{abstract}

\section{Introduction}

1. On 18 July 2013 the Court of Justice of the European Union (CJEU) gave its long awaited decision in European Commission \& the Council of the European Union $v$ Yassin Abdullah Kadi (Kadi (CJEU II)). ${ }^{1}$ This decision followed only a few months after the European Court of Human Rights (ECtHR) handed down its decision in Nada $v$ Swritzerland. ${ }^{2}$ Both decisions concerned the predicament of individuals who were listed by the sanctions committee of the United Nations Security Council (UNSC), which was established in accordance with UNSC resolution 1267 (1999) and sustained by subsequent resolutions. ${ }^{3}$ This sanctions committee (hereinafter referred to as the Al Qaida sanctions committee) was a sub-organ of the UNSC and its composition mirrored that of the UNSC. UNSC Resolution 1267 (1999) and its followup resolutions, which were all adopted under Chapter VII of the United Nations Charter, invested the $A l$ Qaida sanctions committee with the power to identify (through listing) individuals and entities that were suspected of involvement with the Taliban and Al Qaida. Member states in which listed individuals or

\footnotetext{
* Co-Director, Institute for International and Comparative Law in Africa and Professor of International Law, University of Pretoria (South Africa); Professor of International Constitutional Law, Universiteit van Amsterdam, (The Netherlands); email: erika.dewet@up.ac.za

${ }^{1}$ European Commission \& the Council of the European Union v Yassin Abdullah Kadi, joined Cases C-584/10 P, C-593/10 P and C-595/10 P [2013] ECR not yet reported (Jul. 18, 2013) [hereinafter Kadi CJEU II]. This case was preceded by Yassin Adullah Kadi v. Council of the European Union and Commission of the European Commmunities, Case T-315/01 [2005] ECR II-3649 (Sep. 21, 2005) [hereinafter Kadi GC 1]; P Yassin Abdullah Kadi and Al Barakaat International Foundation v. Council of the European Union and Commission of the European Communities, Joined Cases C-402/05 P and C-415/05 [2008] ECR I-6351 (Sep. 3, 2008) [hereinafter Kadi CJEU I]; and Yassin Abdullah Kadi v European Commission, Case T-85/09 [2010] ECHR II-0000 (Sep. 30, 2010) [hereinafter Kadi GC II].

2 Nada v Switzerland, Appl. No. 10593/08, ECtHR, (Judgment) [Grand Chamber] (Sep. 12, 2012).

3 SC Res. 1267 (Oct. 15, 1999); subsequent SC resolutions which confirmed the essence of this resolution and expanded on it, include in particular SC Res. 1333 (Dec. 19, 2000); SC Res. 1390 (Jan. 28, 2002); SC Res. 1455 (Jan, 17, 2003); SC Res. 1526 (Jan. 30, 2004); SC Res. 1617 (Jul. 29, 2005); SC Res. 1735 (Dec. 22, 2006); SC Res. 1822 (Jun. 30, 2008) and SC Res. 1904 (Dec. 17, 2009).
} 
entities resided were obliged to freeze their assets, impose travel bans and also prevent the supply of arms. ${ }^{4}$

2. In addition, these individuals and entities had no recourse to an independent and impartial judicial procedure at the United Nations level where they could refute the allegations against them. The only body authorized to consider de-listing in accordance with UNSC Resolution 1267 (1999) and its follow-up resolutions, was the $\mathrm{Al}$ Q Qaida sanctions committee. This procedure was inter-governmental in nature and listed individuals and entities had not direct access to the sanctions committee. More-over, the sanctions committee functioned by means of unanimity, as a result of which each member state could veto a delisting request. The listing and de-listing procedures were essentially political in nature and were neither dependent on a statement of reasons nor conducted transparently. ${ }^{5}$

3. On 19 December 2006 the UNSC adopted Resolution 1730 (2006) which introduced the so-called Focal Point for receiving de-listing requests. However, the Focal Point merely transmitted the requests for de-listing to the Al Qaida sanctions committee and did not amend the decision-making procedure within the sanctions committee. ${ }^{6}$ The most meaningful qualitative improvement from the perspective of listed individuals and entities has been the introduction of the Ombudsperson through UNSC Resolution 1904 (2009), who replaced the Focal Point in relation to the Al Qaida sanctions committee. She can receive information from petitioners and states, assess the information and make suggestions ('observations') to the sanctions committee regarding de-listing. ${ }^{7}$ By 31 July 2013, her efforts have resulted in the de-listing of 20 individuals and 24 entities since the establishment of her office in 2010.8 However, despite the undisputed relief that her conscientious efforts have brought to those de-listed, the ultimate decision for de-listing remains a political one in the hands of the sanctions committee and the UNSC. ${ }^{9}$

4. Through the adoption of Resolutions 1988 and 1989 on 17 June 2011, the UNSC introduced separate sanctions committees for dealing with the threats posed by the Taliban and Al Qaida, respectively. Resolution 1988 introduced the new Taliban sanctions committee that had the competence to list individuals and entities who constituted a threat to peace, stability and security in Afghanistan. Those listed by the Taliban committee still faced the freezing of their assets and travel bans, as was the case when they were still under the auspices of the Al Qaida sanctions committee. ${ }^{10}$ However, they no more had access to the Ombudsperson and the requirements for their de-listing were effectively reversed to what it was before the introduction of the Ombudsperson. ${ }^{11}$

\footnotetext{
${ }^{4}$ SC Res. 1267 (Oct. 15, 1999), paras. 4 and 6; Dire Tladi \& Gillian Taylor, On the Al Qaida/ Taliban Sanctions Regime: Due Process and Sunsetting, 10 Chinese JIL 771 et seq. (2011).

${ }^{5}$ See Tladi \& Taylor, supra note 4 , at 775.

${ }^{6}$ Tladi \& Taylor, supra note 4, at 781.

7 SC Res. 1904 paras. 20-21 (Dec. 17, 2009); see extensively Tladi \& Taylor, supra note 4, at 782.

${ }^{8}$ UN Doc. S/2013/71 para. 5 (Jan 31, 2013).

${ }^{9}$ See also Kadi (GC II), supra note 1, at para. 128; Tladi \& Taylor, supra note 4, 782.

${ }^{10}$ SC Res. 1988 paras. 1,6, 21 (Jun. 17, 2011).

${ }^{11}$ Individuals who were moved from the Consolidated List of the Al Qaida sanctions committee to the separate list of the Taliban sanctions committee through the adoption of SC Res. 1988 (June. 17, 2011) suddenly found themselves without any access to the ombudsperson. For a critical analysis see Tladi \& Taylor, supra note 4, at 786.
} 
5. In accordance with UNSC Resolution 1989 of 17 June 2011, the ombudsperson procedure currently only applies to the Al Qaida sanctions committee. This resolution further introduced a diluted sunset clause. It determines that once the Ombudsperson recommended de-listing or a state requested delisting, such de-listing should occur unless all members of the Al Qaida sanctions committee disagreed with the recommendation or request within a 60 day period. ${ }^{12}$ However, this reversal of the procedure from 'consensus required for de-listing' to 'consensus required for continued listing' does not result in automatic de-listing where no consensus for continued listing can be achieved. If any state disagrees to the requested de-listing within the 60 day period, the matter is referred to the UNSC on request of that state and the UNSC then has to take the decision concerning de-listing within 60 days. ${ }^{13}$ Given that in practice it usually is one of the permanent members opposing the de-listing in the sanctions committee, de-listing will also be blocked in the UNSC itself by a veto. Moreover, these amendments did not change the intergovernmental, essentially political nature of the de-listing process. ${ }^{14}$

6. The continued absence of an independent judicial procedure at the United Nations level where listed individuals and entities can refute allegations of terrorism against them, over time gave rise to disputes before regional and domestic courts in Europe in particular. These proceedings focused on the legality of the measures implementing the AlQaida sanctions regime. In the case of Mr. Kadi, this saga was played out before the courts of the European Union (EU), due to the fact that the implementing measures were undertaken at the EU level on behalf of the EU member states. In the case of Mr. Nada, the dispute initially unfolded before the Swiss domestic courts, in light of the fact that Switzerland is not a member of the EU and implemented the Al Qaida sanctions regime autonomously. Subsequent to a finding by the Swiss Federal Tribunal (the highest court in the country) that UNSC Resolution 1267 (1999) effectively suspended Mr. Nada's right to a fair hearing, ${ }^{15}$ he initiated a complaint at the ECtHR in Strasbourg.

7. As will be illuminated in the subsequent sections, the Kadi and Nada decisions both resulted in the favoring of human rights above UNSC obligations, while applying very different reasoning. Both sets of reasoning are bound to be very influential, as they involved two of Europe's most powerful and prestigious courts. Whereas the ECtHR informs the jurisprudence of 47 states that constitute the membership of the Council of Europe, the CJEU impacts the legal developments in 27 states which make up the EU. Moreover, all 27 EU member states (two of which are permanent members of the UNSC) are also members of the Council of Europe and therefore need to take into consideration the jurisprudence of both the ECtHR and the CJEU. In addition, these two courts have often in the past influenced the jurisprudence of other domestic courts around the world. The importance of their reasoning in the Kadi and Nada decisions for the efficacy of UNSC sanctions regimes therefore is self-evident and justifies closer scrutiny.

\footnotetext{
12 SC Res. 1989 paras. 23, 27 (Jun. 17, 2011).

${ }^{13}$ SC Res. 1989 paras. 23, 27 (Jun. 17, 2011)

14 Tladi \& Taylor, supra note 4 at, 781,787.

15 Youssef Mustapha Nada v Staatssekretariat für Wirtschaft, Case No 1A 45/2007 BGE, 133 II 450 (Nov. 14, 2007); ILDC 461 (CH 2007).
} 
8. The Kadi dispute in particular has been extensively debated in literature. ${ }^{16}$ It initially unfolded in 2005 before the then still Court of First Instance (currently known as the General Court) of the EU. This court considered Mr. Kadi's listing to be immune from judicial scrutiny, as it originated from a binding UNSC sanctions regime that left no discretion for implementation. ${ }^{17}$ From there Mr. Kadi launched a successful appeal (hereinafter referred to as Kadi CJEU I) to the Court of Justice of the European Union (CJEU). ${ }^{18}$ The CJEU formally separated the implementing measures at EU level from the measures taken by the UNSC and the Al Qaida sanctions committee. It applied a dualist approach in as far as it engaged in review of the implementing measures, without formally challenging the primacy of the UNSC measures at the international level. ${ }^{19}$ This formal separation was motivated by the fact that within the EU legal order fundamental rights (such as the right to judicial protection), formed an integral part of the general and constitutional order which could not be sacrificed. ${ }^{20}$ The CJEU then ordered the implementing measures to be annulled, due to the fact that the EU authorities did not communicate any reasons to Mr. Kadi regarding his listing, nor had they afforded him any opportunity to be heard. ${ }^{21}$

9. Subsequently the EU provided Mr. Kadi with a summary of reasons that has been made available by the Al Qaida sanctions committee and allowed him a hearing, but only to dismiss his response and reinstate the sanctions on the EU level.22 Mr. Kadi once again turned to the the General Court which following the line of reasoning of the CJEU - determined that the reasons forwarded to Mr. Kadi were too vague to allow for meaningful review. The measures implementing the UNSC sanctions at EU level were therefore once again struck down. ${ }^{23}$

10. This decision gave rise to another appeal to the CJEU, this time by the European Commission and Council of the EU and which was decided on 18 July 2013.24 Supported by several EU member states, the appellants urged the CJEU to reconsider its position that judicial immunity should not be granted to EU listings that give effect to the Al Qaida sanctions regime. According to this line of argument, the EU was under a strict obligation to give effect to these obligations and had been left with

\footnotetext{
${ }^{16}$ See e.g. Antonios Tzanakopoulos, Collective Security in Human Rights, in Hierarchy in International Law. The Place of Human Rights 42 et seq. (E. de Wet \& J. Vidmar, eds., 2012); Erika de Wet, Human Rights Considerations and the Enforcement of Targeted Sanctions in Europe: the Emergence of Core Standards of Judicial Protection, in Securing Human Rights? Achievements and Challenges of the UN Security Council 141 et seq. (B. Fassbender ed., 2011); Gráinne de Búrca, The ECJ and the International Legal Order after Kadi 51 HILJ 1et seq. (2010); Andrea Gattini, Joined Cases C-402/05 P \& 415/05 P, Yassin Abdullab Kadi, Al Barakaat International Foundation v. Council and Commission, judgment of the Grand Chamber of 3 September 2008, 46 CMLR 213, 221 (2009); Pasquale De Sena and Maria Chiara Vitucci, The European Courts and the Security Council: between Dédoublement Fonctionnel and Balancing of Values, 20 EJIL 193 et seq. (2009). This provoked three three responses by respectively Gráinne de Búrca, André Nollkaemper and Iris Canor, all titled Three Replies to Pasquale De Sena and Maria Chiara Vitucci, in 20 EJIL 853 et seq (2009).

${ }^{17}$ Kadi (GC I), supra note 1, at paras. 221 et seq.; see also Antonios Tzanakopoulos, Kadi Showdown: Substantive Review of (UN) Sanctions by the ECJ sec. IV (Jul. 26, 2013), available at www.ejiltalk.org/kadi-showdown/\#more-8613; Tladi \& Taylor, supra note 4, at 779.

18 Kadi (CJEU I), supra note 1.

${ }^{19}$ See also Kadi (EGC II), supra note 23, at para. 119.

${ }^{20}$ Kadi (CJEU I), supra note 1, at para. 288.

${ }^{21}$ Kadi (CJEU I), supra note 1, at para. 334; see also Tzanakopoulos, supra note 17, at sec. II.

22 Tzanakopoulos, supra note 17, at sec. II- III.

${ }^{23}$ Kadi (GC II), supra note 1, at para. 157; Tzanakopoulos, supra note 17, at sec. II; Tladi \& Taylor, supra note 4, at 780 .

${ }^{24}$ Kadi (CJEU II), supra note 1.
} 
no discretion regarding the manner of implementation, as a result of which these measures should be immune from judicial review. ${ }^{25}$ Realizing perhaps that the CJEU was highly unlikely to reverse its position on the lack of immunity of the implementing measures (which it indeed reaffirmed rather summarily), 26 the appellants further attempted to lower the level of scrutiny applied during judicial review. This was inspired by the fact that the EU institutions lacked any margin of discretion in relation to the manner of implementing the measures stemming from the Al Qaida sanctions regime. ${ }^{27}$ However, this argument failed to impress the court which retained its high level of scrutiny in reviewing and striking down the reasons submitted by the EU organs in relation to Mr. Kadi's listing.

11. The current contribution will proceed with an overview of the benchmarks for judicial protection that were endorsed in Kadi (CJEU II). It will also indicate how these benchmarks were applied in the Kadi (CJEU II) case, as this was the first time that the CJEU engaged in a thorough review of the reasons for listing. The contribution will however not revisit the reasoning of the previous Kadi decisions, which have been extensively analyzed elsewhere. ${ }^{28}$ Instead, it will thereafter focus on the different techniques applied by the CJEU and the ECtHR, in order to ensure judicial protection for individuals whose human rights are curtailed by decisions of the UNSC.

12. Whereas the CJEU relied exclusively on its own internal legal order for providing judicial protection to the affected individuals or entities, the ECtHR resorted to the technique of harmonious interpretation. This technique is otherwise known as the principle of systemic integration and is also concretized in Article 31(3)(c) of the Vienna Convention on the Law of Treaties of 1969. This sub-article determines that when interpreting a treaty, account shall be taken of 'any relevant rules of international law applicable in the relations between the parties.' ${ }^{29}$ By applying this technique, the courts in question attempted to reconcile apparent contradictory obligations stemming from a UNSC resolution on the one hand, and international human rights standards on the other.

13. The contribution will further assess the implications of these techniques, as the differences between them can have consequences for the efficacy of UNSC sanctions regimes. In addition, they can impact the role and relevance of international law in sustaining a balance between human rights and international peace and security.

\footnotetext{
${ }^{25}$ See also Tzanakopoulos, supra note 17 , at sec. II.

${ }^{26} \mathrm{Kadi}$ (CJEU II), supra note 1, at paras. 59-69.

${ }^{27}$ Kadi (CJEU II), supra note 1, at paras. 72-73; Tzanakopoulos, supra note 17, at sec. IV. A similar (ultimately unsuccessful) line of reasoning was suggested by Advocate-General Bot in his opinion to the CJEU regarding Joined Cases C-584/10 P, C-593/10 P and C-595/10 P European Commission, Council of the European Union, United Kingdom of Great Britain and Northern Ireland v Yassin Abdullab Kadi paras. 53 et seq. (Mar. 19, 2013), available at http://eurlex.europa.eu/LexUriServ/LexUriServ.do?uri=CELEX:62010CC0584:EN:NOT.

${ }^{28}$ See e.g. sources cited supra, note 16.

29 Art. 31 (3)(c), Vienna Convention on the Law of Treaties (May 23,1969), U.N.T.S. vol 1155, at 331.
} 


\section{The benchmarks for judicial protection within the EU legal order}

14. In the Kadi (CJEU II) decision of July 2013, the CJEU reaffirmed that fundamental rights, one of which is judicial protection, formed an integral part of the general and constitutional principles of the EU. These principles, could not be prejudiced by an international agreement, be it the United Nations Charter or otherwise, despite the fact that the treaty in question maintains its primacy under international law. ${ }^{30}$ The CJEU further reiterated the benchmarks of judicial protection which had to be respected by those organs of the EU which are responsible for the implementation and execution of the respective UNSC targeted sanctions regime on behalf of EU member states. In essence, these benchmarks rest on two pillars, namely the right to be heard vis-à-vis the EU authorities, such as the Council of the EU and judicial review involving the EU courts. ${ }^{31}$

\section{II.A. The right to be heard}

15. Within the EU legal order the right to be heard applies to all decisions that can culminate in a measure adversely affecting the person in question. In relation to targeted sanctions it would first require that the competent EU authority provides the listed persons with a statement of reasons for listing or maintaining their listing. Thereafter the listed persons must be provided with the opportunity to make their views known. Finally, the competent EU authority must examine carefully and impartially the soundness of the reasons, considering also the rebuttals of the affected person and any exculpatory evidence. $^{32}$

16. A particular bone of contention remains the scope of the statement of reasons to be given to the listed individuals. According to the CJEU, this statement has to be sufficiently specific and concrete in relation to the individual in question. It has to give a concrete indication as to why a specific individual was listed. ${ }^{33}$ The CJEU accepted that not all evidence needed to be disclosed ${ }^{34}$ and that a summary of reasons, such as that provided by the AlQaida sanctions committee, could suffice. ${ }^{35}$ However, the decisive point is that the listed individuals must be in a position to make known their views effectively in relation to the grounds advanced against them. They must be able to decide, with full knowledge of the relevant facts, whether there is any point in bringing an action before the EU courts. ${ }^{36}$

17. The respective competent EU authority has to consider also exculpatory evidence provided by the listed individual. In order to enable it to engage in a careful and impartial assessment of all the facts,

\footnotetext{
${ }^{30}$ Kadi (CJEU II) supra note 1, at para. 97.

${ }^{31}$ Ibid., at paras. 98-99.

32 Ibid., at paras. 100, 135.

33 Ibid., at para. 116.

34 This is also in line with ECtHR jurisprudence, e.g. Chabal v United Kingdom, App. No. 22414/93, (Judgment) [Grand Chamber] para. 131 (Nov. 15, 1996).

35 See also Kadi (CJEU I), supra note 1, at para. 344; and the (then still) Court of First Instance in Melli Bank v Council, Joined Cases T-246/08 and T-332/08 [2009] ECR II-2629 (Jul. 9, 2009).

${ }^{36} \mathrm{Kadi}$ (CJEU II), supra note 1, at paras. 111-112.
} 
the relevant EU authority may need to request the Al Qaida sanctions committee to disclose to it confidential or other relevant information in its possession. Similarly, the EU authority may need to request the $A l$ Qaida sanctions committee to assist it in obtaining such information from the particular United Nations member state which proposed the listing. ${ }^{37}$ The CJEU based this obligation on the principle of effective cooperation embodied in Article 220(1) of the Treaty on the Functioning of the European Union, which governs the relationship between the EU and the United Nations in matters of international peace and security. ${ }^{38}$

18. By underscoring the importance of the information in possession of the Al Qaida sanctions committee and United Nations member states, the CJEU implicitly acknowledged that the EU organs are often dependant on this information in order to make an informed decision. Yet, the CJEU also implicitly acknowledged that the Al Qaida sanctions committee or other United Nations member states are under no obligation to share the relevant (and often confidential) evidence with the competent EU authority. The CJEU determined that the mere fact that an EU authority does not make accessible to the listed persons (or subsequently to the EU courts) evidence that is in the sole possession of a sanctions committee or a United Nations member state, does not in and of itself amount to a violation of the right to judicial protection. ${ }^{39}$ However, the matter does not end there, for there remains an obligation on the EU authorities to provide the necessary evidence themselves. If they are not able to do so, the EU courts will have to exercise their review on the basis of that information that is available to them. If that material is insufficient for determining that a reason for listing is well-founded in relation to the individual in question, such reasons cannot be relied on as the basis for the listing. ${ }^{40}$

19. It is worth nothing that the Kadi (CJEU II) decision left intact previous decisions pertaining to the timing of the right to be heard. In accordance with previous jurisprudence of the EU courts, this right is triggered only after the listing (and subsequent freezing of assets) have occurred. Once an individual or entity has been listed, the reasons for doing so must be communicated as soon as possible. Similarly, it is not necessary that states first institute and await the outcome of criminal proceedings prior to participating in the listing of individuals in their territory. ${ }^{41}$

\footnotetext{
${ }^{37}$ Ibid., at paras. 114-115.

${ }^{38}$ Ibid., at para. 115. See also Art. 20(1), Treaty of the Functioning of the European Union, O.J. C 115/47 (May 5, 2009).

39 The CJEU noted that the General Court erred in Kadi (GC II), supra note 1, at paras. 181, 183-184, when determining that the lack of access of a listed individual or the EU courts to information which an EU organ does not have in its possession, as such constituted a violation of the right to judicial protection. See Kadi (CJEU II) supra note 1, at para. 139; Tzanakopoulos, supra note 17, at sec. IV.

${ }^{40}$ Kadi (CJEU II), supra note 1, at paras. 120-124; 137; Tzanakopoulos, supra note 17, at sec. IV.

${ }^{41}$ See inter alia Kadi (CJEU I), supra note 1, at para 339. The position of the EU courts can be distinguished from that of the Human Rights Committee (HRC) in Sayadi and Vinck v Belgium, UN Doc. CCPR/C/94/D/1472/2006 (Dec. 29, 2008). The HRC concluded that by transmitting the names of Mr Sayadi and Ms Vinck to the Al Qaida sanctions committee in accordance with SC Res. 1267 (Oct. 15, 1999), without awaiting the outcome of the national criminal investigation, Belgium was responsible for the resulting infringement of their right to liberty of movement as protected by Article 12 ICCPR. As a result of the listing the couple was not allowed to travel within or leave Belgium. However, the approach suggested by the HRC would compromise the purpose of the listing procedure which is aimed at swift and effective action.
} 


\section{II.B. The right to judicial revien}

20. The second pillar of judicial protection within the EU legal order concerns the right to judicial review before the General Court and the CJEU - a right that applies regardless of whether the freezing of assets amounts to a criminal charge. ${ }^{42}$ For this review to be meaningful, the European courts must be placed in a position to determine whether the EU authority responsible for the listing has carefully applied its mind to all the relevant facts; whether the facts actually support the conclusions drawn by that authority, and whether the EU authorities have given sufficient consideration to any exculpatory evidence. This implies that the provision of a statement of reasons for the listing is not only a crucial element of a fair hearing before the competent EU authorities, but also essential for enabling the respective EU court to verify the factual accuracy of the reasons underpinning the listing. ${ }^{43}$

21. When engaging in such a verification, the court cannot restrict itself to an abstract assessment of the reasons relied on, but needs to determine whether at least one of the reasons is substantiated by evidence that directly relates to the listed person concerned. The need for substantiated evidence is necessitated by the procedural rights of the listed individual during an adversarial process. This in turn implies that at least one of the reasons must be sufficiently detailed and specific in order to serve as basis for the listing. This also applies in situations where some of the nature and sources of evidence may be withheld for security reasons, or where disclosure of evidence takes the form of a summary of reasons. ${ }^{44}$

22. In applying these criteria to the summary of reasons provided by the Al Qaida sanctions committee in relation to Mr. Kadi, the CJEU found four of the five reasons sufficiently detailed and specific. However, none of these reasons were substantiated by evidence and in all instances Mr. Kadi provided plausible, alternative explanations. The first reason related to the fact that Mr. Kadi was a founding trustee and directed the activities of the Muwafaq Foundation which was allegedly absorbed into Al Qaida in 2001. The reason was sufficiently detailed and specific, as it identified the link between $A l$ Qaida/ Usama bin Ladin and a particular entity, as well as Mr. Kadi's role in the entity. ${ }^{45}$ However, no evidence has been produced to substantiate the allegations of the Muwafaq Foundation's involvement with Al Qaida. Mr. Kadi for his part underscored that the Muwafaq Foundation had an exclusively charitable character and submitted documentation indicating that it had ceased operation by 1998.46

23. The second reason for listing concerned the appointment of Mr. Al-Ayadi by Mr. Kadi in 1992, as manager of the European offices of the Muwafaq Foundation. According to the statement of reasons, Mr. Kadi made this appointment on the recommendation of Mr. Julaidan, a financier who had fought

\footnotetext{
$42 \mathrm{EU}$ courts were initially at pains to comment on the non-punitive, precautionary nature of asset freezing, as illustrated by the (then still) Court of First Instance in Mohamed El Morabit v Council, Joined cases T-37/07 and T323/07 [2009] ECR I-0000, paras. 40, 51, 52 (Sep. 2, 2009). However, in Kadi (GC II), supra note 1, at para. 150, the General Court cautioned that measures which have been in place for more than ten years can hardly be described as temporary and precautionary. See also Kadi (CJEU II), supra note 1, at para. 132.

${ }^{43}$ Kadi (CJEU II), supra note 1, at para. 119; Kadi (GC II), supra note 1, at paras. 89, 93, 143, 145.

${ }^{44} \mathrm{Ibid}$., at para. $119 \mathrm{ff}$.

45 Ibid., at para. 143.

$46 \mathrm{Ibid}$, at paras. 151, 153.
} 
alongside Usama bin Laden in Afghanistan in the 1980s. The reason sufficiently indicated the time and context of the appointment of Mr. Al-Ayadi and a link between himself and Usama bin Laden. However, in light of the lapse of time since the events in 1992 - which formed the basis of the listing - the CJEU did not regard this second reason for listing as well-founded anymore. It noted that even if the material based on events in 1992 were sufficient for supporting a listing in 2002, it was not sufficient for maintaining a listing after 2008, in the absence of any other substantiating evidence. ${ }^{47}$ It is further noteworthy that according to Mr. Kadi, Mr. Al-Ayadi was recommended to him on the basis of his expertise and that the exclusive purpose of the Muwafaq Foundation in Europe was to provide support to refugees from Bosnia and Croatia during the Balkans conflict in the 1990s. He also underscored that at that time Usama bin Ladin was still regarded as an ally of the West against the Soviet Union in Afghanistan and it was only as of 1996 that he was labeled as a terrorist. ${ }^{48}$

24. The third reason was based on a statement allegedly made in 1995 by Mr Talad Fuad Kassem, the leader of the Al-Gama'at al Islamiyya, to the effect that during the 1990s the Muwafaq Foundation provided - alongside Usama bin Ladin - logistical and financial support to a mujahidin battalion in Bosnia and Herzegovina. Once again, the reason specifically indicated the type and time of the alleged terrorist activity and the source of this information. However, not only did Mr. Kadi claim no knowledge of or involvement with Mr. Talad Fuad Kassem, but was no evidence submitted by means of which the accuracy of the statement attributed to Mr. Talad Fuad Kassem could be verified. ${ }^{49}$

25. The fourth reason was based on the fact that Mr. Kadi was one of the major shareholders in the Bosnian bank Depositna Banka (now closed), in which Mr Al-Ayadi held a position and acted as nominee for Mr Kadi. It was alleged that planning sessions for an attack in association with Usama bin Ladin against a United States facility in Saudi Arabia may have taken place within this bank. While the reason sufficiently identified the financial institution through which Mr. Kadi allegedly contributed to terrorist activities and the nature of the alleged terrorist project concerned, no evidence has been produced that supported the claim pertaining to the planning sessions. ${ }^{50}$ Mr Kadi also denied ever having provided financial support to international terrorism through Depositna Banka or through any other entity. His interest in the bank was exclusively for commercial reasons and the appointment of a Bosnian national in the form of Mr. Al-Ayadi as his nominee was in order to comply with the requirements of the local law. 51

26. Finally, the last reason submitted in the summary of reasons already failed the first hurdle of specificity. According to the summary provided by the Al Qaida sanctions committee, Mr. Kadi had been the owner of several Albania firms which directed money to extremists and which received working capital from Usama bin Laden. The allegation was insufficiently detailed, as it gave no indication of the

\footnotetext{
47 Ibid., at para. 156.

48 Ibid., at para. 144-145, 154.

${ }^{49}$ Ibid., at paras. 156-157.

${ }^{50}$ Ibid., at paras. 148-149.

51 Ibid., at para. 162.
} 
identity of the firms or extremists concerned, nor the timing of the alleged conduct. ${ }^{52}$ In essence therefore, none of the allegations presented against Mr Kadi in the summary provided by the Al Qaida sanctions committee were such as to justify the adoption, at EU level, of restrictive measures against him. Even to the extent that the reasons provided were sufficiently specific, they remained unsubstantiated in the face of detailed rebuttals submitted by Mr. Kadi. ${ }^{53}$

\section{II.C. Assessing the judicial technique applied by the CJEU}

27. The Kadi (CJEU II) decision confirmed that the standard of judicial protection provided within the EU legal order amounts to full judicial review of the merits, also where restrictive measures vis-à-vis individuals or entities have their origins in a binding Chapter VII resolution of the UNSC. In fact, the benchmarks for judicial protection recognized in the Kadi case closely resemble those developed by the General Court in the Organisation des Modjahedines du Peuple d'Iran (OMPI) cases. ${ }^{54}$ Whereas the Kadi case concerned the implementation of listings that were directly undertaken by the Al Qaida sanctions committee, the OMPI cases concerned the implementation of listings adopted autonomously within the EU pursuant to UNSC Resolution 1373 (2002). 55

28. This resolution required states to adopt various measures for the purpose of combating international terrorism. However, it did not provide a UNSC sanctions committee with the competence to engage in direct listing or de-listing of individuals for the purpose of assets freezing or imposing travel bans. Instead, it left states (or regional organizations that act on their behalf) with a broad discretion in determining their own listing procedures in accordance with their respective legal systems. The CJEU nonetheless applied similar levels of judicial protection in relation to the implementing measures stemming from these different regimes. This effectively amounts to a rejection of different levels of judicial protection within the EU, depending on the degree of discretion that the wording of a UNSC sanctions regime provided for in relation to its implementation. This undoubtedly places EU member states - which are all also members of the United Nations - in a difficult position. They are forced to disobey either a decision of the CJEU or a UNSC resolution, which will trigger state responsibility under either the one or the other regime..$^{56}$

29. Be that as it may, judicial deference by the European courts to the listing and de-listing procedures of UNSC sanctions committees will remain unlikely, until such a time as the sanctions committee in question provides independent judicial protection. This can be concluded from the statement by the CJEU that judicial review by the EU courts remain essential since, despite the improvements added to the

\footnotetext{
52 Ibid., at para. 141.

53 Ibid., at para. 163.

${ }^{54}$ Case T-228/02, Organisation des Modjahedines du Peuple d'Iran v Council [2006] ECR II-4665 (OMPI I) (Dec. 12, 2006); Case T-256/07, People's Mojabedin Organization of Iran v Council [2008] ECR II-03019 (OMPI (II)) (Oct 23, 2008); Case T-284/08, People's Mojabedin Organization of Iran v Council (OMPI (III) (Dec. 4, 2008).

55 SC Res. 1373 (Sep.28, 2001).

56 See also Tzanakopoulos, supra note 17 , at sec. III.
} 
delisting procedure at the United Nations level, this procedure does not amount to effective judicial protection. ${ }^{57}$ Although Mr. Kadi himself has been delisted in December 2012 and is unlikely to initiate any further proceedings, other EU residents listed by the Al Qaida sanctions committee may still avail themselves of the EU courts. The same applies to those individuals and entities listed by the Taliban sanctions committee and other country specific sanctions committees with the competence to engage in direct listing. ${ }^{58}$ These individuals and entities do not even have access to an Ombudsperson and are entirely dependent on the inter-governmental, political procedure for de-listing as exercised by their respective sanctions committees.

30. As long as this situation prevails, the EU courts are likely to apply a high level of scrutiny when reviewing EU measures that are aimed at implementing listings stemming directly from a UNSC sanctions committee. It is fair to say that the warning signal sent by be the CJEU has already yielded some results. Had it not been for the persistent judicial revolt by the CJEU since its first Kadi decision in 2008, it is doubtful whether any of the (admittedly modest) reforms of the Al Qaida sanctions regime would have been introduced at the United Nations level.

31. However, from a systemic perspective, the approach of the CJEU carries with it the risk of the devaluation of international human rights law, as well as of legal uncertainty. Its benchmarks for judicial protections are based purely on EU law and leave unanswered the question whether and to what extent the UNSC has to act in accordance with international human rights standards. The exclusive reliance on EU law further fuels the perception that an irreconcilable norm conflict exists between a UNSC sanctions regime and domestic or regional regimes that value the protection of human rights - a conflict which could only be resolved by rejecting UNSC obligations. This in turn can have a fragmentary effect on the unified system foreseen in the United Nations Charter for the maintenance of international peace and security.

32. In addition, the CJEU's approach leads to a situation of legal uncertainty ('limping situations'), due to the fact that its decisions for annulment are binding on the EU authorities, but not on the UNSC or any of its (sub-)organs. The EU courts do not have the judicial competence to order the UNSC or its sanctions committees to de-list any particular individual, nor to introduce effective judicial protection at the international level. Therefore, while the European courts can order the competent EU authorities not to give effect to a particular listing by a UNSC sanctions committee, the listing will formally remain intact at the UNSC level. This will remain the case until such a time as the UNSC sanctions committee itself delists the affected individual or entity.

\footnotetext{
${ }^{57}$ Kadi (CJEU II), supra note 1, at para. 133.

58 Such as the sanctions committee pursuant to SC Res. 1483 (May 22, 2003); see also (text leading up to) FN 81 infra.
} 


\section{Human rights friendly interpretation of UNSC Resolutions in the jurisprudence of the ECtHR}

33. A question that arises from the above analysis is if and to what extent the systemic challenges resulting from the dualist technique applied by the CJEU can be overcome by the technique of harmonious (human rights friendly) interpretation followed by the ECtHR. The subsequent paragraphs will examine the implications of the two leading cases in this regard, namely Al Jedda $v$ the United Kingdom ${ }^{59}$ and Nada. Whereas the former case concerned the interpretation of a UNSC resolution that left states with some discretion in terms of its method of implementation, hardly any such discretion was available in relation to the UNSC measures applicable to Mr. Nada. ${ }^{60}$

\section{III.A. Interpreting flexible UNSC Resolutions}

34. The Al-Jedda case was the first case in which the ECtHR expressed a clear reluctance to assume that the UNSC intended to limit international human rights disproportionately (let alone suspend them) through binding decisions. The case concerned the issue whether the internment without trial of a British/ Iraqi national by British forces in Iraq in 2004 violated Article 5(1) ECHR. The (then still) House of Lords accepted the argument of the British government that UNSC Resolution 1546 of 8 June 2004, which was adopted under Chapter VII of the United Nations Charter, served as a legal basis for internment - despite the fact that this ground for detention was not covered by the exhaustive list contained in Article 5(1) ECHR. Paragraph 10 of Resolution 1546 (2004) authorized the multi-national force in Iraq (in which British forces participated) "to take all necessary measures to contribute to the maintenance of security and stability in Iraq in accordance with the letters annexed to this resolution...". These letters concerned those to the President of the UNSC from the Prime Minister of the Interim Government of Iraq and the United States Secretary of State. They elaborated inter alia on the tasks of the multi-national force, referring also to internment for security purposes. ${ }^{61}$

35. As far as the (then still) House of Lords was concerned, UNSC Resolution 1546 (2004) in combination with article 103 of the United Nations Charter necessitated a deviation from article 5(1) ECHR. Lord Bingham (with whom the majority of the House of Lords agreed), underscored the overriding character that Article 103 attributed to Charter obligations in the event of a conflict with obligations under any other international agreement. ${ }^{62} \mathrm{He}$ further emphasized that in light of the immense

59 Al-Jedda v United Kingdom, Appl. No. 27021/087, ECtHR, (Judgement) [Grand Chamber] (Jul. 7, 2011).

${ }^{60}$ One of the first authors to underscore the potential of human rights friendly interpretations of obligations stemming from the Resolution 1267 (1999) sanctions regime was Jose Alvarez, The Security Council's War on Terrorism: Problems and Policy Options, in Review of the Security Council by Member States 134 (E. de Wet \& A. Nollkaemper, eds, 2003).

${ }^{61}$ As acknowledged also by the ECtHR in Al-Jedda, supra note 59, at paras. 103, 105.

${ }^{62} \mathrm{R}$ (on the application of Al-Jedda) v Secretary of State for Defence [2007] UKHL 58, Opinion of Lord Bingham, at para. 37 (Dec. 12, 2007). However, Lord Bingham (as did a majority of the House of Lords) accepted that the UK forces in 
importance of the maintenance of international peace and security, such obligations (in this instance those resulting from UNSC Resolution 1546) should not be narrowly interpreted. As a result, the members of the multi-national force should be able to intern individuals where necessary for security reasons. Since this would in turn lead to an inevitable conflict with Article 5(1) ECHR, the latter had to be overridden. ${ }^{63}$

36. The ECtHR for its part rejected the broad interpretation given to UNSC obligations in the interest of international peace and security. Although the ECtHR accepted that obligations under the United Nations Charter prevailed over any other conflicting international obligation, ${ }^{64}$ it was extremely reluctant to accept that such a conflict indeed existed in this instance. Instead, it introduced a strong presumption in favor of a human rights friendly intention on the part of the UNSC. The ECtHR underscored that Article 24(2) of the United Nations Charter required the UNSC to act in accordance with the purposes and principles of the United Nations, one of which was the promotion of international human rights. ${ }^{65}$ This fact was also noted by the House of Lords, but was apparently outweighed in its mind by security considerations. ${ }^{66}$ The ECtHR however, determined that in the event of any ambiguity in the wording of a UNSC Resolution, the court had to choose that interpretation which was most in harmony with the requirements of the ECHR and which avoided any conflict of international obligations. ${ }^{67}$ The UNSC would thus have to use clear and explicit language in the respective resolution itself, if it intended states to take measures that would conflict with a state's international human rights obligations.

37. When applying these considerations to the situation of Mr. Al-Jedda, the ECtHR concluded that UNSC Resolution 1546 (2004) did not contain a clear intention to oblige members of the multi-national force to resort to indefinite internment in a manner that violated their international human rights obligations. First, the preamble of Resolution 1546 (2004) did specifically mention the commitment of all forces to act in accordance with international law. Second, the resolution itself did not refer to internment; instead it was mentioned in the annexed letters as an example of a broad range of measures pertaining to security. Third, paragraph 7 of UNSC Resolution 1456 (2004) mandated the United Nations SecretaryGeneral and the United Nations Assistance Mission for Iraq to promote the protection of human rights in Iraq. Both entities have on occasion criticized the extensive use of internment by the multi-national forces in Iraq. From these 'human rights friendly' references the ECtHR induced an intention on the part of the UNSC, to oblige the members of the multi-national force to achieve the maintenance of security in Iraq in accordance with their international human rights obligation. ${ }^{68}$

Iraq had effective control over Mr. Al-Jedda and that the ECHR was applicable in the circumstances, see ibid., paras 6-25.

${ }^{63}$ Ibid., at paras. $37-39$.

${ }^{64}$ Al-Jedda (ECtHR), supra note 59, at para. 101.

${ }^{65}$ Ibid.

${ }^{66}$ Al Jedda (HoL), supra note 60, at para. 37.

${ }^{67}$ Al-Jedda (ECtHR), supra note 59, at paras. 102.

${ }_{68}$ Al-Jedda (ECtHR), supra note 59, at paras. 104-105, 106. In paras. 107-109, the ECtHR further rejected the argument that international humanitarian law placed a clear obligation on an occupying power (to the extent that the UK could be regarded as such in Iraq) to use indefinite internment without trial. 
38. In essence therefore, it seems that it is unlikely that the ECtHR will accept any intention on the part of the UNSC to deviate from international human rights obligations of member states, unless this is required in so many words by a UNSC resolution itself. ${ }^{69}$ Where this is not the case states will have to prove that they have indeed done everything in their power to prevent the suspension of their international human rights obligations, when giving effect to UNSC obligations. ${ }^{70} \mathrm{How}$ difficult this task can be, even in instances where the UNSC resolution leaves significantly less scope for interpretation than was the case with UNSC Resolution 1546 (2004), can be illustrated by the Nada case. As mentioned in the introductory section above, Mr. Nada was listed by the Al Qaida sanctions committee in accordance with the UNSC Resolution 1267 (1999) sanctions regime. However, due to the fact the implementing measures in question were adopted by Switzerland which is not in the EU, any review of the legality of these measures had to be undertaken by Swiss courts.

\section{III.B. Interpreting inflexible UNSC Resolutions}

39. As a result of his listing in accordance with the Resolution 1267 (1999) sanctions regime in November 2001, Mr. Nada was subjected to a freezing of assets, as well as stringent travel restrictions and had no course to judicial review. The travel restrictions, which effectively confined him to the Italian enclave in Switzerland where he lived, inter alia complicated his access to medical care outside the enclave. This was problematic in light of his health condition and his age.

40. At the domestic level, the Swiss Federal Tribunal (Switzerland's highest court) acknowledged that the de-listing procedure foreseen by the UNSC Resolution 1267 (1999) sanctions regime was not compatible with the right to a fair hearing in article 6(1) of the ECHR, to which Switzerland is a party. However, it also referred to Switzerland's obligation under Article 103 of the Charter to give precedence to UNSC obligations in case of a conflict with other obligations under international law. ${ }^{71}$ It concluded that since the de-listing procedure left no room for interpretation, Mr. Nada's right to a fair hearing in Article 6(1) ECHR was necessarily suspended. ${ }^{72}$

41. This case, which was decided in November 2007, closely followed the reasoning of the first Kadi case before the General Court (which was decided in 2005) and before the CJEU reversed this decision on appeal in September 2008 in Kadi (CJEU I). Although Switzerland is not a member of the EU, it tried to follow the line of reasoning of the EU courts, but entirely misjudged how the case would play out on appeal. As a result, the Swiss Federal Tribunal has found itself increasingly isolated within Europe since September 2008 in relation to its reasoning concerning the interpretation of UNSC sanctions.

69 Al-Jedda (ECtHR), supra note 59, at para. 102.

${ }^{70}$ The position of the ECtHR in Al Jedda was also echoed in the separate opinion of Sir Nigel Rodley in the Sayadi \& Vinck decision of the HRC, supra note 41. He argued that the over-arching criterion for interpretation was the presumption that the UNSC did not intend actions pursuant to its resolutions that violated international human rights standards.

${ }^{71}$ Nada (Swiss Federal Tribunal), supra note 15.

${ }^{72}$.Ibid. 
42. Subsequent to the decision of the Swiss Federal Tribunal, Mr. Nada filed a complaint against Switzerland with the ECtHR in Strasbourg. This complaint was directed at Switzerland's state responsibility under the ECtHR for violating notably the right to private and family life in Article 8(1) of the ECHR, as well as the right to a remedy in Article 13(1) ECHR. ${ }^{73}$ While acknowledging the restrictive language of the relevant UNSC resolutions, The ECtHR did not accept that Switzerland had no discretion of any kind when implementing these measures. The ECtHR's point of departure was whether Switzerland had done everything within its power to minimize the conflict between UNSC Resolutions and the obligations resulting from the ECHR and concluded that this had not been the case.

43. As far as Article 8(1) ECHR is concerned, the ECtHR inter alia underscored that already by 2005 the investigations by the Swiss authorities have concluded that the suspicions about Mr. Nada's involvement in international terrorism were unfounded. It also closed the criminal investigation against him that was opened in 2001. Even so, the Swiss authorities only informed the Al Qaida sanctions committee about its findings in September 2009, a few weeks after which Mr. Nada was de-listed by this committee. The ECtHR rebuked the Swiss authorities for this almost four year delay in transmitting its findings, especially since no reason was provided for such a delay. Had here been no such delay, Mr. Nada may have been de-listed much earlier. ${ }^{74}$ Similarly, Switzerland interpreted the humanitarian exceptions in the respective UNSC resolutions too restrictively, as a result of which Mr. Nada had too limited opportunity to travel for medical reasons. ${ }^{75}$ According to the ECtHR, Switzerland should have considered more carefully the circumstances of the case (such as the health and age of Mr. Nada, his geographical location and the duration of the sanctions) when giving effect to the sanctions regime. In essence therefore, Switzerland has failed to show that it has done everything possible to harmonize its obligations under Article 8(1) ECtHR with its obligations resulting from the Resolution 1267 (1999)sanctions regime, thereby violating Article 8(1) ECHR. ${ }^{76}$

44. The ECtHR further determined that Switzerland should have provided Mr. Nada with access to judicial review on the domestic level, by means of which he could have verified those measures implementing the Resolution 1267 (1999) sanctions regime. Mr. Nada therefore had no effective means to obtain an exemption from the implementing measures at the domestic level, which amounted to a violation of Article 13(1) ECHR. ${ }^{77}$ In coming to this conclusion the ECtHR made a curt reference to the Kadi (CJEU I) decision and also noted that de-listing procedure at the United Nations level did not amount to an effective remedy. ${ }^{78}$ Moreover, it claimed that there was nothing in the Resolution 1267 (1999) sanctions regime that prevented the Swiss authorities from providing effective judicial review mechanisms on the domestic level. ${ }^{79}$ This can be interpreted as implying that a sanctions regime such as

\footnotetext{
${ }^{73}$ Nada (ECtHR), supra note 2, at paras. 163 et seq.

${ }^{74} \mathrm{Nada}$ (ECtHR), supra note 2, at paras. 187-188.

75 Ibid., at paras. 190-192

${ }^{76}$ Ibid., at paras. 195-197, 199.

77 Ibid., at paras. 211-213.

78 Ibid., at paras. 211-212.

${ }^{79}$ Ibid., at para. 212.
} 
the one resulting from Resolution 1267 (1999) necessarily and implicitly allows states the discretion needed to enforce the respective sanctions regime in accordance with international human rights standards.

45. Such an interpretation would amount to assuming the permissibility of judicial review in accordance with the standards of the ECHR (or other applicable international human rights instruments), unless this was explicitly excluded. In practice, this would place implementing states and the affected individuals and entities in a similar situation of legal uncertainty, as would result from a consistent enforcement of the Kadi (CJEU II) decision. Whereas the individuals would regain access to their assets and freedom of movement within a particular jurisdiction, they would remain formally listed ('targeted') at the United Nations level, until such as time as the respective sanctions committee de-listed them. Furthermore, states which delisted individuals on the domestic level subsequent to a court decision to this effect may trigger state responsibility on the international level for acting in contravention with a UNSC obligation. In the case of Mr. Nada these two consequences will not arise, as he has since also been delisted by the Al Qaida sanctions committee.

46. However, for Switzerland this is not the end of the matter. Subsequent to deciding the Nada case - and before this case was decided by the ECtHR - the Swiss Federal Tribunal reiterated its position about the primacy of UNSC obligations vis-à-vis international human rights standards in two other decisions. Whereas one of these cases also concerned the $A l$ Qaida sanctions committee, ${ }^{80}$ the other decision concerned the freezing of assets of individuals and entities that were associated with the Iraqi regime of Saddam Hussein, as well as the immediate transfer of those assets to the Development Fund of Iraq in accordance with Resolution 1483 of 22 May 2003.81 These individuals and entities were directly identified by the sanctions committee set up under UNSC Resolution 1518 of 24 November 200382 which has a delisting procedure similar to that of the Taliban sanctions committee pursuant to UNSC Resolution 1988 (2011)). As these cases are likely to follow the same route as the Nada decision and with the same result, Switzerland is again likely to find itself before difficult legal choices in the immediate future. ${ }^{83}$

80 A v Federal Department of Economics, Case No. No 1A48/2007, Swiss Federal Tribunal [Judgment] (Apr. 22, 2008), ILDC 1201 (CH 2008).

${ }_{81}$ A v Federal Department of Economics, Case No. 2A 783/2006, Swiss Federal Tribunal [Judgment] (Jan. 23, 2008) ILDC 1200 (CH 2008); SC Res. 1483 paras. 19, 23 (May 2, 2003). This resolution has since been succeeded by SC Res 1518 (Nov. 24, 2005) which established a new sanctions committee responsible for inter alia listing activities. See http://www.un.org/sc/committees/1518/ilist.shtml.

82 SC Res. 1518 (Nov. 24, 2003).

${ }^{83}$ The impact of the ECtHR's reasoning in the Nada case almost immediately made itself felt in The Netherlands $v$ A and Others [2012] LJN: BX8351, Supreme Court of the Netherlands (Judgment) (Dec. 14, 2012). The case concerned the domestic measures implementing SC Res. 1737 para. 17 (Dec. 23, 2006). It called on 'all States to exercise vigilance and prevent specialized teaching or training of Iranian nationals, within their territories or by their nationals, of disciplines which would contribute to Iran's proliferation of sensitive nuclear activities and development of nuclear weapon delivery systems'. The Court rejected the argument that this paragraph necessitated the exclusion of Iranian nationals from certain specialized disciplines at Dutch universities. Such an interpretation would violate the principle of non-discrimination in Art. 26 ICCPR. The Dutch government had not provided convincing arguments why it could not follow less restrictive measures, as was practiced in neighbouring countries. 
III.C. Assessing the judicial technique applied by the ECtHR

47. The line of reasoning introduced by the ECtHR in Al-Jedda and continued in Nada, reflects that ECHR member states are under an obligation to show that it has done as much as possible to prevent a disproportionate limitation of ECHR standards by a particular UNSC resolution. This includes a stringent requirement for motivating why a state had not chosen less restrictive means of implementation. The more latitude the language of a UNSC resolution leaves a state for implementation, the more difficult it would be to justify a method of implementation that restricts human rights. However, the Nada decision of the ECtHR has indicated that even where the language of a UNSC resolution leaves no apparent scope for interpretation, states remain under an obligation to find a way to give some effect to international human rights standards. The presumption that the UNSC did not intend to deviate from human rights standards seems to be almost irrebuttable, even where it would amount to a distortion of the text of a UNSC decision.

48. The great advantage of the technique of systemic integration is that it finds a solution for conflicts between international obligations within the international legal order itself and thereby strengthens the unity of international law. ${ }^{84}$ In the Al-Jedda and Nada cases, the technique prevented an open rejection of UNSC resolutions by individual states, which could result in undermining a unified system for the protection of international peace and security. This risk is inherent in the dualist approach followed by the CJEU in the Kadi cases, since it regards international law as irrelevant for deciding the norm conflict. When applying the technique of systemic integration on the other hand, states remain bound to give effect to UNSC resolutions even though the scope of these obligations is limited by human rights obligations through interpretation. Systemic integration therefore reduces the risk of an open rebellion against and destabilization of the United Nations system for the protection of international peace and security. Stated differently, systematic integration contributes to the unity of the international legal order and serves as a counter-force against fragmentation of international law.

49. Even so, one has to concede that the technique is only convincing where it does not lead to a distortion of the text of the competing international obligations at stake. The Al-jedda decision exemplifies a case where the technique was applied convincingly, i.e. in a manner that did not contradict the text of the UNSC resolution. The texts of the relevant resolution was sufficiently flexible to allow for the interpretation chosen by the ECtHR. The Nada decision on the other hand, would amount to an overstretching of the technique. It effectively distorted the wording of a UNSC sanctions regime and can result in the same type of 'limping scenarios' that can potentially result from the reasoning in the Kadi decisions. In essence, the Nada decision is not so much an illustration of harmonious interpretation as an example of

\footnotetext{
${ }^{84}$ See extensively Erika de Wet \& Jure Vidmar, Conclusions, in Hierarchy in International Law. The Place of Human Rights, 305 et seq. (E. de Wet \& J. Vidmar, eds., 2012).
} 
covert rejection of (or a covert rebellion against) UNSC obligations which are perceived as violating human rights norms that are fundamental to the states affected as well as the United Nations itself.

50. In the final analysis, the techniques for interpretation applied in both the Nada and Kadi sagas ultimately shifted the resolution of the norm conflict back to the political arena. The overriding message from the CJEU and the ECtHR is that extensive reform is required in relation to all the de-listing procedures of those sanctions committees that engage in direct listing and de-listing. Until such a time as impartial and independent judicial review is introduced at the United Nations level for those individuals and entities directly listed by UNSC sanctions committees, judicial rebellion - whether through dualist techniques or systemic integration - are unlikely to subside in Europe.

\section{[11 643 words]}

